\title{
Organocatalyzed diastereoselective Henry reaction of enantiopure 4-oxoazetidine-2-carbaldehydes
}

\author{
Benito Alcaide, ${ }^{\mathrm{a}^{*}}$ Pedro Almendros, ${ }^{\mathrm{b}^{*}}$ Amparo Luna, ${ }^{\mathrm{a}} \mathrm{M}$. Paz de Arriba, ${ }^{\mathrm{a}}$ and \\ M. Rosario Torres ${ }^{\mathrm{c}}$ \\ a Departamento de Química Orgánica I, Facultad de Química, Universidad Complutense de \\ Madrid, 28040-Madrid, Spain \\ E-mail: alcaideb@quim.ucm.es \\ bInstituto de Química Orgánica General, CSIC, Juan de la Cierva 3, 28006-Madrid, Spain \\ E-mail:iqoa392@iqog.csic.es \\ ${ }^{c}$ Laboratorio de Difracción de Rayos X, Facultad de Química, Universidad Complutense de \\ Madrid, 28040-Madrid, Spain
}

\section{Dedicated to Prof. Joan Bosch on the occasion of his $60^{\text {th }}$ birthday}

\begin{abstract}
The Henry reaction of enantiopure 4-oxoazetidine-2-carbaldehydes with nitromethane was catalyzed by $(+)-N$-methylephedrine $[(+)-\mathrm{NME}]$ as well as $(-)-\mathrm{NME}$, to give the corresponding nitroaldols with reasonable yields and moderate diastereoselectivities. The obtained results implied that $(2 R, 3 R)$-4-oxoazetidine-2-carbaldehydes and $(+)$-NME are a matched pair for diastereoselective induction.
\end{abstract}

Keywords: Asymmetric induction, Henry reaction, $\beta$-lactams, organocatalysis

\section{Introduction}

The 2-azetidinone ( $\beta$-lactam) skeleton is well established as the key pharmacophore of $\beta$-lactam antibiotics, the most widely employed class of antibacterial agents. ${ }^{1}$ In addition, there are many important nonantibiotic uses of 2-azetidinones in fields ranging from enzyme inhibition ${ }^{2}$ to gene activation. ${ }^{3}$ Apart from their clinical interest, the use of $\beta$-lactams as versatile synthons for the preparation of compounds of biological relevance, such as $\alpha$ - and $\beta$-amino acids, alkaloids, heterocycles, and taxoids, ${ }^{4}$ has triggered a renewed interest in the building of new $\beta$-lactam systems. In addition, the chiral $\beta$-amino alcohol moiety is a common structural fragment in numerous biologically important molecules such as dipeptide isosteres, statine and its analogues. The presence of this moiety and the configuration of the carbon atom bearing the hydroxy as 
well as the amino group play a vital role in the biological activity of the molecules containing it, and therefore, its stereocontrolled synthesis remains an intensive research area. ${ }^{5}$ On the other hand, nucleophilic carbonyl addition reactions can be ranked among the premier transformations in organic synthesis for stereoselective carbon-carbon bond formation. In particular, the aldol reaction constitutes a fundamental synthetic methodology. ${ }^{6}$ In contrast to the catalytic asymmetric aldol reaction, the analogous reaction involving nitroalkane donors (Henry reaction) has evolved at a relatively slow pace, ${ }^{7}$ although the nitro moiety on the nitroaldols can be further functionalized. ${ }^{8}$ During the course of our ongoing project directed toward developing efficient routes to prepare chiral functionalized 2-azetidinones and their synthetic applications, ${ }^{9}$ we have described the proline-catalyzed diastereoselective direct aldol reaction between enantiopure 4oxoazetidine-2-carbaldehydes and ketones. ${ }^{10}$ In connection with this work, we wish to report here the catalytic nitroaldol reaction between enantiopure 4-oxoazetidine-2-carbaldehydes and nitromethane.

\section{Results and Discussion}

4-Oxoazetidine-2-carbaldehydes 1a-e, were prepared in optically pure form using standard methodology. ${ }^{9}$ Enantiopure 2-azetidinone $(+)-2$ was obtained as single cis-enantiomer from the corresponding imine of $(R)-2,3-O$-isopropylideneglyceraldehyde, through Staudinger reaction with acetoxyacetyl chloride in the presence of $\mathrm{Et}_{3} \mathrm{~N}$. Transesterification of 3-acetoxy-2azetidinone (+)-2 with sodium methoxide in methanol gave the corresponding alcohol, which by treatment with $p$-methoxybenzoyl chloride under basic conditions, gave the 2-azetidinone $(+)-3$. Selective acetonide hydrolysis promoted by bismuth(III) chloride of compound ( + )-3 followed by oxidative cleavage of the resulting diol smoothly provided 4-oxoazetidine-2-carbaldehyde $(+)-1 e$ (Scheme 1).

Having obtained the starting substrates, the next stage was set to carry out the nitroaldol derivatives formation. On the basis of a recent precedent in the literature, ${ }^{11}$ the combination of zinc(II) triflate, diisopropylethylamine (Hünig's base) and (+)- $N$-methylephedrine [(+)-NME] was selected. Treatment of $\beta$-lactam aldehyde $(+)$-1a with nitromethane under the optimized conditions (24 hours at $-24{ }^{\circ} \mathrm{C}$, using $\mathrm{Zn}(\mathrm{OTf})_{2}, i \operatorname{Pr}_{2} \mathrm{EtN}$, and $(+)-\mathrm{NME}$ in ratio of 30:30:45 (mol $\%)$ promoted complete conversion to the corresponding nitroaldol syn-(+)-4a, which was obtained stereoselectively in moderate yield (Scheme 2). Slower reactions and decreased chemical yields of the Henry adducts were noted by performing the nitroaldol reaction in methylene chloride at lower temperatures $\left(-50^{\circ} \mathrm{C}\right)$. 
<smiles>CC(=O)O[C@H]1C(=O)N([Pb])[C@H]1[C@H]1COC(C)(C)O1</smiles>

(+)-2

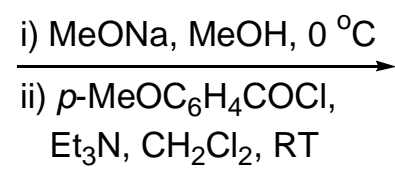

$\mathrm{Et}_{3} \mathrm{~N}, \mathrm{CH}_{2} \mathrm{Cl}_{2}, \mathrm{RT}$

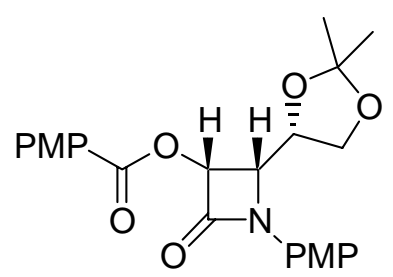

(+)-3 (96\%)

iii) $\mathrm{BiCl}_{3}, \mathrm{CH}_{3} \mathrm{CN}, \mathrm{H}_{2} \mathrm{O}$, RT

iv) $\mathrm{NaIO}_{4}, \mathrm{NaHCO}_{3}$ (aq. sat.), $\mathrm{CH}_{2} \mathrm{Cl}_{2}$, RT<smiles>N#[Y16]C(=O)O[C@H]1CC(=O)N1[Y6]#P</smiles>

(+)-1e (67\%)

\section{Scheme 1}

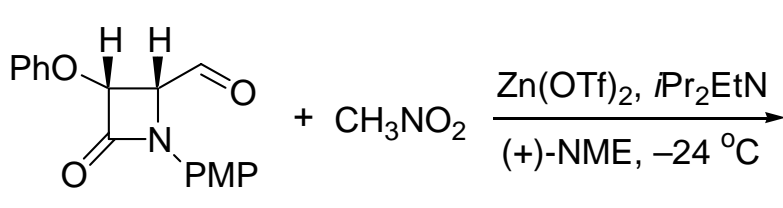

$(+)-1 a$

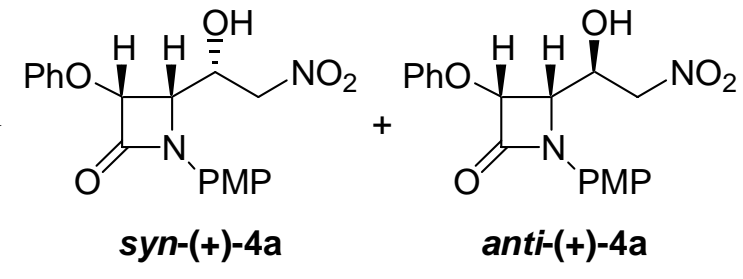

$60 \%$, syn/anti ratio $=80: 20$

\section{Scheme 2}

Due to environmental concerns, there is a need for metal-free chemistry. As a consequence, organocatalysis has emerged as a new tool to efficiently perform organic reactions with high enantio- and diastereoselectivity under very mild and simple conditions. ${ }^{12}$ From a wide variety of known organocatalysts, perhaps the most remarkable is proline. Not only has this compound been studied more extensively than the others, as the first example of an organocatalyst, it is also an abundant and inexpensive chiral molecule available in both enantiomeric forms. Proline has thus become one of the most widely used organocatalysts today. In view of our previous results on the direct catalytic asymmetric aldol reaction of $\beta$-lactam aldehydes, ${ }^{10}$ we decided to examine the feasibility and efficiency of the proline-catalyzed nitroaldol reaction of enantiopure 4oxoazetidine-2-carbaldehydes 1. Unfortunately, proline was unable to promote this nitroaldol reaction (Table 1, entry 1). Interestingly, however, $(+)$-NME itself was capable of promoting the Henry reaction between $\beta$-lactam aldehyde $(+)$-1a and nitromethane (Table 1, entry 2 ) in a slightly higher diastereoselectivity than using Palomo's conditions. ${ }^{11}$ Consequently, NME was selected as the catalyst of choice for all further reactions. Subsequently, it was found that 4- 
oxoazetidine-2-carbaldehydes $\mathbf{1 b}-\mathbf{e}$ reacted with nitromethane using $(+)$-NME catalysis under standardized conditions to yield $\beta$-lactam nitroaldols $\mathbf{4 b - e}$ (Table 1). Since no total asymmetric induction is observed for the reaction of aldehydes $\mathbf{1}$ with nitromethane in the presence of catalytic amounts of (+)-NME, it was decided to see the effect of the chirality of NME on the nitroaldol process. However, slightly lower stereoselectivity was obtained using (-)-NME. A representative selection of 4-oxoazetidine-2-carbaldehydes $\mathbf{1}$ was evaluated and the results are gathered in Table 1.

Table 1. Synthesis of nitroaldol derivatives $\mathbf{4}^{a}$

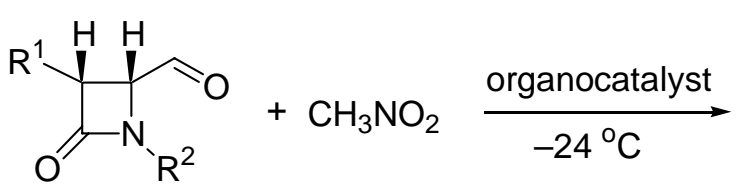

1

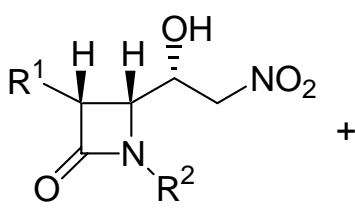

syn-4

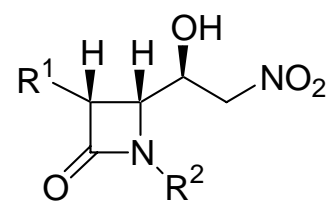

anti-4

\begin{tabular}{|c|c|c|c|c|c|c|c|}
\hline Entry & Aldehyde & $\mathrm{R}^{1}$ & $\mathrm{R}^{2}$ & Organocatalyst & Product & $\begin{array}{c}\text { syn/anti } \\
\text { Ratio }^{b}\end{array}$ & Yield $(\%)^{c}$ \\
\hline 1 & $(+)-1 a$ & $\mathrm{PhO}$ & PMP & L-proline & syn-(+)-4a & - & - \\
\hline \multirow[t]{8}{*}{2} & $(+)-\mathbf{1 a}$ & $\mathrm{PhO}$ & PMP & $(+)-\mathrm{NME}$ & syn-(+)-4a & $90: 10$ & 81 \\
\hline & $(+)-\mathbf{1 a}$ & $\mathrm{PhO}$ & PMP & $(-)-\mathrm{NME}$ & syn- $(+)-\mathbf{4 a}$ & $80: 20$ & 81 \\
\hline & $(+)-\mathbf{1 b}$ & $\mathrm{PhO}$ & allyl & $(+)-N M E$ & syn-(+)-4b & $80: 20$ & 63 \\
\hline & $(+)-\mathbf{1 b}$ & $\mathrm{PhO}$ & allyl & $(-)-N M E$ & syn-(+)-4b & $70: 30$ & 72 \\
\hline & $(+)-1 c$ & $\mathrm{MeO}$ & PMP & $(+)-\mathrm{NME}$ & syn- $(+)-4 c$ & $80: 20$ & 65 \\
\hline & $(+)-1 c$ & $\mathrm{MeO}$ & PMP & $(-)-\mathrm{NME}$ & syn- $(+)-4 c$ & $80: 20$ & 69 \\
\hline & $(+)-1 d$ & $\mathrm{MeO}$ & $p-\mathrm{BrC}_{6} \mathrm{H}_{4}$ & $(+)-\mathrm{NME}$ & syn-(+)-4d & $85: 15$ & $45^{d}$ \\
\hline & $(+)-1 d$ & $\mathrm{MeO}$ & $p-\mathrm{BrC}_{6} \mathrm{H}_{4}$ & (-)-NME & syn-(+)-4d & $80: 20$ & $63^{d}$ \\
\hline 10 & $(+)-1 e$ & PMPCO & PMP & $(+)-\mathrm{NME}$ & syn-(+)-4e & $90: 10$ & $46^{e}$ \\
\hline 11 & $(+)-1 e$ & PMPCO & PMP & $(-)-N M E$ & syn- $(+)-\mathbf{4 e}$ & $75: 25$ & $55^{e}$ \\
\hline
\end{tabular}

${ }^{a} 45 \mathrm{Mol} \%$ of $N$-methylephedrine was used except otherwise stated. PMP $=4-\mathrm{MeOC}_{6} \mathrm{H}_{4} \cdot{ }^{b} \mathrm{The}$ ratio was determined by integration of well-resolved signals in the ${ }^{1} \mathrm{H}$ NMR spectra $(300 \mathrm{MHz})$ of the crude reaction mixtures before purification. ${ }^{c}$ Combined yield of isolated nitroaldol products with correct analytical and spectral data. ${ }^{d}$ The diastereomeric nitroaldols syn-(+)-4d and anti-(+)-4d could be easily separated by gravity flow chromatography. ${ }^{e}$ The diastereomeric nitroaldols $s y n-(+)-4 \mathbf{e}$ and anti-(+)-4e could be easily separated by gravity flow chromatography.

No partial inversion of configuration was involved in the transformation of aldehydes $\mathbf{1}$ to nitroaldols 4 . The assignment of the cis-configuration to $\beta$-lactams $\mathbf{4}$ was based on the observed coupling constants of about $5.0 \mathrm{~Hz}$ for methine protons $\mathrm{H} 3$ and $\mathrm{H} 4$, whereas trans-configuration is consistent with methine coupling constants of ca. $2.0 \mathrm{~Hz}$ in their ${ }^{1} \mathrm{H} \mathrm{NMR}$ spectra. ${ }^{13}$ 
Derivatizing the nitroalcohols 4 with $(R)$ - and $(S)$-O-acetylmandelic acids would allow the assignment of the configuration at the carbinolic stereocenter. However, sluggish and low yielding reactions were observed. This behavior of the 2 -azetidinone-tethered nitroaldol adducts resembles our results with $\beta$-lactam aldols, ${ }^{10}$ which is in sharp contrast with the good yields observed by us for related $O$-acetylmandelates derived from homoallylic or $\alpha$-allenic alcohols. ${ }^{14}$ Fortunately, the configurational assignment for the nitroaldol series was established by X-ray crystallography of the adduct syn-(+)-4e (Figure 1$).{ }^{15}$

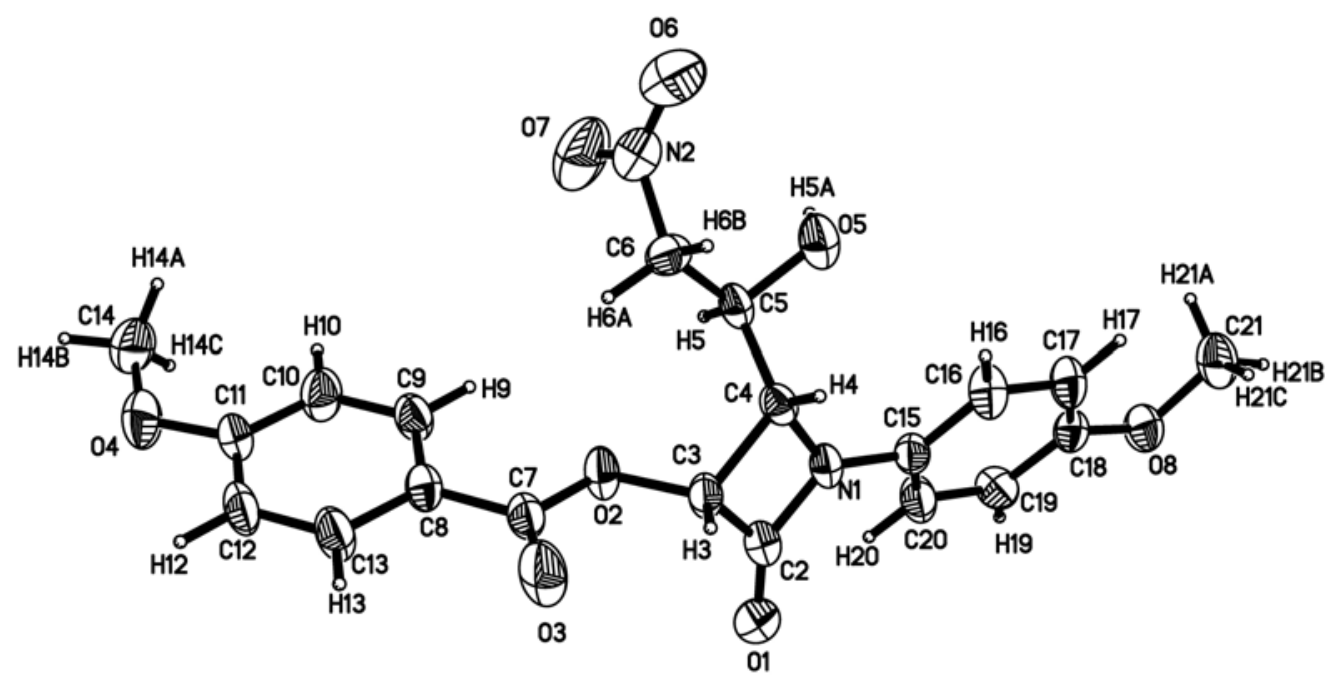

\section{Figure 1}

It is apparent, that face selectivity for addition to the carbonyl group is preferentially dictated by the absolute configuration of the chiral aldehyde. The observed slightly higher selectivity for the (+)-NME-catalyzed reaction of 4-oxoazetidine-2-carbaldehydes can be rationalized as the cumulative effect of steric inhibitions posed by the chiral aldehyde and the facial preference of the organocatalyst (favored, match). The slightly poorer selectivity encountered in the case of ()-NME could be explained due to the opposite preference of the $\beta$-lactam aldehyde and the organocatalyst (disfavored, mismatch).

\section{Conclusions}

The present study provides the first insight into the asymmetric manner in which 4-oxoazetidine2-carbaldehydes and nitromethane undergo an organocatalyzed coupling to give nitroaldol adducts, being the $\beta$-lactam aldehyde/(+)-NME couple a matched pair for diastereoselectivity induction. 


\section{Experimental Section}

General Procedures. ${ }^{1} \mathrm{H}$ NMR and ${ }^{13} \mathrm{C}$ NMR spectra were recorded on a Bruker Avance-300, Varian VRX-300S or Bruker AC-200. NMR spectra were recorded in $\mathrm{CDCl}_{3}$ solutions, except otherwise stated. Chemical shifts are given in ppm relative to TMS $\left({ }^{1} \mathrm{H}, 0.0 \mathrm{ppm}\right)$, or $\mathrm{CDCl}_{3}\left({ }^{13} \mathrm{C}\right.$, $76.9 \mathrm{ppm}$ ). Low and high resolution mass spectra were taken on a HP 5973 spectrometer using the electronic impact mode (EI), or on a HP Series 1100MSD spectrometer using the electrospray mode (ES). Specific rotation $[\alpha]_{\mathrm{D}}$ is given in $10^{-1} \mathrm{deg} \mathrm{cm}^{2} \mathrm{~g}^{-1}$ at $20^{\circ} \mathrm{C}$, and the concentration $(c)$ is expressed in $\mathrm{g}$ per $100 \mathrm{~mL}$. All commercially available compounds were used without further purification.

Preparation of 2-azetidinone (+)-3. Acetoxyacetylchloride $(38 \mathrm{mmol})$ in anhydrous dichloromethane $(25 \mathrm{~mL})$ was added dropwise via syringe to a solution of 2,3-O(isopropylidene)-D-glyceraldehyde $p$-anisyl imine $(25 \mathrm{mmol})$ and $\mathrm{Et}_{3} \mathrm{~N}$ (75 mmol) in dichloromethane $(160 \mathrm{~mL})$, at $0{ }^{\circ} \mathrm{C}$ under argon. The resulting mixture was allowed to warm to room temperature, and was stirred for $16 \mathrm{~h}$. The crude mixture was diluted with $\mathrm{CH}_{2} \mathrm{Cl}_{2}(100$ $\mathrm{mL})$ and washed with saturated $\mathrm{NaHCO}_{3}$ and brine. The organic layer was dried $\left(\mathrm{MgSO}_{4}\right)$ and concentrated under reduced pressure. Chromatography of the residue eluting with ethyl acetate/hexanes (3/7) gave analytically pure (3R,4S)-3-acetoxy-4-(1,3-dioxolan-4-yl)-1-(4methoxyphenyl)-2-azetidinone (+)-2. Sodium methoxide $(341 \mathrm{mg}, 6.30 \mathrm{mmol})$ was added in portions at $0{ }^{\circ} \mathrm{C}$ to a solution of the acetoxy- $\beta$-lactam $(+)-2(6.30 \mathrm{mmol})$ in methanol $(60 \mathrm{~mL})$. The reaction was stirred for $20 \mathrm{~min}$. and then water was added $(10 \mathrm{~mL})$. The methanol was removed under reduced pressure, the aqueous residue was extracted with ethyl acetate and the organic layer was dried $\left(\mathrm{MgSO}_{4}\right)$. The solvent was removed under reduced pressure, to give analytically pure $(3 R, 4 S)-4-(1,3-$ dioxolan-4-yl)-3-hydroxy-1-(4-methoxyphenyl)-2-azetidinone. Then, $p$-methoxybenzoyl chloride (205 mg, $1.2 \mathrm{mmol}$ ), DMAP (cat.), and triethylamine (304 mg, $3 \mathrm{mmol}$ ) were sequentially added dropwise to a stirred solution of the alcohol (293 $\mathrm{mg}, 1.0$ $\mathrm{mmol})$ in dichloromethane $(10 \mathrm{~mL})$ at $0{ }^{\circ} \mathrm{C}$, and the mixture was stirred at room temperature for 2h. Chromatography of the residue using ethyl acetate/hexanes (3/1) gave $411 \mathrm{mg}(96 \%)$ of analytically pure compound $(+)-3$ as a colorless solid.

2-Azetidinone (+)-3. Mp $134-136{ }^{\circ} \mathrm{C}$ (hexanes/ethyl acetate). $[\alpha]_{\mathrm{D}}=+52.5$ (c $0.6, \mathrm{CHCl}_{3}$ ). NMR data: $\delta_{\mathrm{H}}\left(\mathrm{CDCl}_{3}\right) 1.31\left(\mathrm{~s}, 3 \mathrm{H}, \mathrm{CH}_{3}\right), 1.49\left(\mathrm{~s}, 3 \mathrm{H}, \mathrm{CH}_{3}\right), 3.68(\mathrm{dd}, 1 \mathrm{H}, J=6.3,8.8 \mathrm{~Hz}$, $\mathrm{CHH}), 3.78\left(\mathrm{~s}, 3 \mathrm{H}, \mathrm{OCH}_{3}\right), 3.85\left(\mathrm{~s}, 3 \mathrm{H}, \mathrm{OCH}_{3}\right), 3.99(\mathrm{dd}, 1 \mathrm{H}, J=6.3,8.8 \mathrm{~Hz}, \mathrm{CH} H), 4.40$ (d, $1 \mathrm{H}, J=4.9 \mathrm{~Hz}, \mathrm{H} 4), 4.43$ (m, 1H, OCH), 6.24 (d, 1H, $J=4.9 \mathrm{~Hz}, \mathrm{H} 3$ ), 6.87 (d, 2H, $J=9.0 \mathrm{~Hz}$, Ar), $6.94(\mathrm{~d}, 2 \mathrm{H}, J=9.0 \mathrm{~Hz}, \mathrm{Ar}), 7.67(\mathrm{~d}, 2 \mathrm{H}, J=9.0 \mathrm{~Hz}, \mathrm{Ar}), 8.01$ (d, 2H, $J=9.0 \mathrm{~Hz}, \mathrm{Ar}) . \delta_{\mathrm{C}}$ $\left(\mathrm{CDCl}_{3}\right) 164.4(\mathrm{C}=\mathrm{O}), 164.3(\mathrm{C}=\mathrm{O}), 162.1,156.6,132.7,132.1,130.8,120.3,119.7,113.9$, 110.0, $76.6(\mathrm{C} 3), 73.1(\mathrm{OCH}), 66.4\left(\mathrm{OCH}_{2}\right), 61.7(\mathrm{C} 4), 55.4\left(\mathrm{OCH}_{3}\right), 55.3\left(\mathrm{OCH}_{3}\right), 26.4\left(\mathrm{CH}_{3}\right)$, $24.9\left(\mathrm{CH}_{3}\right)$. IR $\left(\mathrm{KBr}, \mathrm{cm}^{-1}\right): v 1751(\mathrm{CON}), 1735(\mathrm{COO})$. Anal. Calcd for $\mathrm{C}_{23} \mathrm{H}_{25} \mathrm{NO}_{7}$ : C, 64.63; H, 5.90; N, 3.28. Found: C, 64.74; H, 5.95; N, 3.24. 
Preparation of 4-oxoazetidine-2-carbaldehyde $(+)$ (1e). To a solution of the acetonide $\beta$ lactam $(+)-3(1 \mathrm{mmol})$ in acetonitrile $(10 \mathrm{~mL})$ containing a few drops of water, was added solid $\mathrm{BiCl}_{3}(0.05 \mathrm{mmol})$ in a single portion. The resulting mixture was stirred at room temperature for $24 \mathrm{~h}$, and then was neutralized with solid $\mathrm{NaHCO}_{3}$. The mixture was extracted with ethyl acetate $(3 \mathrm{x} 40 \mathrm{~mL})$, the organic layer was dried $\left(\mathrm{MgSO}_{4}\right)$ and the solvent was removed under reduced pressure. Then, saturated aqueous sodium hydrogen carbonate $(100 \mu \mathrm{L})$ was added to a solution of the corresponding diol $(1.00 \mathrm{mmol})$ in dichloromethane $(6 \mathrm{~mL})$, maintaining the temperature below $25{ }^{\circ} \mathrm{C}$. Solid sodium periodate $(2.00 \mathrm{mmol})$ was added over a $10 \mathrm{~min}$ period with vigorous stirring and the reaction was allowed to proceed for $2 \mathrm{~h}$, while the temperature was maintained below $25{ }^{\circ} \mathrm{C}$. The solid was removed by filtration, the filtrate was dried $\left(\mathrm{MgSO}_{4}\right)$ and the solvent was removed under reduced pressure. The crude product was used for next step without any further purification.

4-Oxoazetidine-2-carbaldehyde (+) (1e). From $143 \mathrm{mg}(0.40 \mathrm{mmol})$ of acetonide $\beta$-lactam $(+)$ 3, $88 \mathrm{mg}(67 \%)$ of aldehyde $(+)-1 e$ was obtained as a colorless solid. Mp: $147-149{ }^{\circ} \mathrm{C}$ (hexanes/ethyl acetate). $[\alpha]_{\mathrm{D}}=+43.8\left(c\right.$ 1.0, $\left.\mathrm{CHCl}_{3}\right)$. NMR data: $\delta_{\mathrm{H}}\left(\mathrm{CDCl}_{3}\right) 3.81(\mathrm{~s}, 3 \mathrm{H}$, $\left.\mathrm{OCH}_{3}\right), 3.88\left(\mathrm{~s}, 3 \mathrm{H}, \mathrm{OCH}_{3}\right), 4.89(\mathrm{dd}, 1 \mathrm{H}, J=2.4,5.4 \mathrm{~Hz}, \mathrm{H} 4), 6.21$ (d, 1H, $\left.J=5.6 \mathrm{~Hz}, \mathrm{H} 3\right)$, 6.91 (d, 2H, $J=9.0 \mathrm{~Hz}, \mathrm{Ar}), 6.93$ (d, 2H, $J=8.8 \mathrm{~Hz}, \mathrm{Ar}), 7.32$ (d, 2H, $J=8.8 \mathrm{~Hz}, \mathrm{Ar}), 7.99$ (d, $2 \mathrm{H}, J=8.8 \mathrm{~Hz}, \mathrm{Ar}), 9.80(\mathrm{~d}, 1 \mathrm{H}, J=2.4 \mathrm{~Hz}, \mathrm{CHO}) . \delta_{\mathrm{C}}\left(\mathrm{CDCl}_{3}\right) 195.9(\mathrm{C}=\mathrm{O}), 164.4(\mathrm{C}=\mathrm{O})$, $160.3(\mathrm{C}=\mathrm{O}), 157.2$, 132.3, 130.2, 118.4, 114.7, 114.0, $75.5(\mathrm{C} 3), 63.1(\mathrm{C} 4), 55.5\left(2 \mathrm{OCH}_{3}\right)$. IR $\left(\mathrm{KBr}, \mathrm{cm}^{-1}\right): v 1752(\mathrm{CON}), 1732(\mathrm{COO}), 1728(\mathrm{CHO})$. Anal. Calcd for $\mathrm{C}_{19} \mathrm{H}_{17} \mathrm{NO}_{6}$ : C, 64.22; H, 4.82; N, 3.94. Found: C, 64.35; H, 4.78; N, 3.91.

General procedure for the Zn/amine/amino alcohol-catalyzed Henry reaction of 4oxoazetidine-2-carbaldehydes

Diisopropylethylamine $(10.4 \mu \mathrm{L}, 0.06 \mathrm{mmol})$ was added to a suspension of $\mathrm{Zn}(\mathrm{OTf})_{2}(21.8 \mathrm{mg}$, $0.06 \mathrm{mmol})$ in $\mathrm{CH}_{3} \mathrm{NO}_{2}(15 \mu \mathrm{L})$, and the slurry was stirred for $1 \mathrm{~h}$ at $25^{\circ} \mathrm{C}$. $(1 S, 2 R)-(+)-N-$ Methylephedrine $(16.1 \mathrm{mg}, 0.09 \mathrm{mmol})$ was then added, and the resulting yellow mixture was stirred for an additional $1 \mathrm{~h}$ at room temperature. After cooling the mixture to $-24{ }^{\circ} \mathrm{C}$ a solution of the appropriate 4-oxoazetidine-2-carbaldehyde $1(0.2 \mathrm{mmol})$ in $\mathrm{CH}_{3} \mathrm{NO}_{2}(50 \mu \mathrm{L})$ was slowly added, and the mixture was stirred at the same temperature for $48 \mathrm{~h}$. The reaction was quenched with a saturated aqueous solution of $\mathrm{NH}_{4} \mathrm{Cl}(0.2 \mathrm{~mL})$, and was allowed to warm to room temperature. The mixture was extracted with ethyl acetate, and the combined organic layer was washed with saturated $\mathrm{NH}_{4} \mathrm{Cl}$. The organic layer was dried with $\mathrm{MgSO}_{4}$ and filtered, and the solvent was removed by evaporation. The crude product was purified by column chromatography to give the corresponding nitroaldol.

General procedure for the organocatalyzed Henry reaction of 4-oxoazetidine-2carbaldehydes. Synthesis of nitroaldols 4

$N$-Methylephedrine $(8.4 \mathrm{mg}, 0.046 \mathrm{mmol}$ ) was added to a well stirred solution of the appropriate $\beta$-lactam carbaldehyde $1(0.10 \mathrm{mmol})$ in nitromethane $(9 \mathrm{~mL})$ cooled at $-25^{\circ} \mathrm{C}$. After $48 \mathrm{~h}$, 
saturated aqueous sodium hydrogen carbonate $(2 \mathrm{~mL})$ was added and the mixture was allowed to warm to room temperature, before being extracted with ethyl acetate $(3 \times 10 \mathrm{~mL})$. The organic extract was washed with brine, dried $\left(\mathrm{MgSO}_{4}\right)$ and concentrated under reduced pressure. Chromatography of the residue eluting with hexanes/ethyl acetate mixtures gave analytically pure compounds $\mathbf{4}$. Spectroscopic and analytical data for some representative forms of $\mathbf{4}$ follow.

Nitroaldol syn-(+) 4a. From $287 \mathrm{mg}(1.0 \mathrm{mmol})$ of aldehyde (+)-1a, after column chromatography eluting with hexanes/ethyl acetate (1:1), $289 \mathrm{mg}(81 \%)$ of nitroaldol syn-(+)-4a was obtained as a pale yellow oil, containing $c a$. 10\% of its anti-2a epimer.

$[\alpha]_{\mathrm{D}}=+202.2\left(c\right.$ 2.3, $\left.\mathrm{CHCl}_{3}\right) . \mathrm{NMR}$ data: $\delta_{\mathrm{H}}\left(\mathrm{CDCl}_{3}\right) 3.80\left(\mathrm{~s}, 3 \mathrm{H}, \mathrm{OCH}_{3}, \mathrm{M}+\mathrm{m}\right), 4.61(\mathrm{~m}, 3 \mathrm{H}$, $\left.\mathrm{CH}_{2}+\mathrm{H} 4, \mathrm{M}+\mathrm{m}\right), 4.96(\mathrm{~m}, 1 \mathrm{H}, \mathrm{CH}-\mathrm{OH}, \mathrm{M}+\mathrm{m}), 5.44(\mathrm{~d}, 0.9 \mathrm{H}, J=5.1 \mathrm{~Hz}, \mathrm{H} 3, \mathrm{M}), 5.49$ (d, 0.1H, $J=5.1 \mathrm{~Hz}, \mathrm{H} 3, \mathrm{~m}), 7.03(\mathrm{~m}, 4 \mathrm{H}, \mathrm{Ar}, \mathrm{M}+\mathrm{m}), 7.40(\mathrm{~m}, 5 \mathrm{H}, \mathrm{Ar}, \mathrm{M}+\mathrm{m}) . \delta_{\mathrm{C}}\left(\mathrm{CDCl}_{3}\right) 166.4(\mathrm{NC}=\mathrm{O}$, $\mathrm{m}), 163.3(\mathrm{NC}=\mathrm{O}, \mathrm{M}), 157.4(\mathrm{C}, \mathrm{Ar}, \mathrm{M}+\mathrm{m}), 157.1(\mathrm{C}, \mathrm{Ar}, \mathrm{M}+\mathrm{m}), 130.1(\mathrm{C}, \mathrm{Ar}, \mathrm{M}+\mathrm{m}), 130.1$ (CH, Ar, M), 123.5 (CH, Ar, M), 122.6 (CH, Ar, m), $122.3(\mathrm{CH}, \mathrm{Ar}, \mathrm{m}), 120.4$ (CH, Ar, M), 119.7 (CH, Ar, m), 116.0 (CH, Ar, M), 114.9 (CH, Ar, m), 114.7 (CH, Ar, M), 114.4 (CH, Ar, m), $79.9(\mathrm{C} 3, \mathrm{M}+\mathrm{m}), 77.8\left(\mathrm{OCH}_{2}, \mathrm{M}+\mathrm{m}\right), 69.0(\mathrm{OCH}, \mathrm{M}), 67.6(\mathrm{OCH}, \mathrm{m}), 59.9(\mathrm{C} 4, \mathrm{~m}), 58.5$ $(\mathrm{C} 4, \mathrm{M}), 55.6\left(\mathrm{OCH}_{3}, \mathrm{M}+\mathrm{m}\right)$. IR $\left(\mathrm{CHCl}_{3}, \mathrm{~cm}^{-1}\right): v 3415(\mathrm{OH}), 1757(\mathrm{C}=\mathrm{O}), 1514\left(\mathrm{NO}_{2}\right)$. MS (ES), $m / z: 359\left(\mathrm{M}^{+}+1,100\right), 358\left(\mathrm{M}^{+}, 11\right)$. Anal. Calcd for $\mathrm{C}_{18} \mathrm{H}_{18} \mathrm{~N}_{2} \mathrm{O}_{6}: \mathrm{C}, 60.33 ; \mathrm{H}, 5.06 ; \mathrm{N}$, 7.82. Found: C, $60.21 ; \mathrm{H}, 5.03 ; \mathrm{N}, 7.77$.

Nitroaldol syn-(+) 4b. From $54 \mathrm{mg}(0.23 \mathrm{mmol})$ of aldehyde (+)-1b, after column chromatography eluting with hexanes/ethyl acetate $(1: 1), 49 \mathrm{mg}(72 \%)$ of nitroaldol syn-(+)-4b was obtained as a colorless oil, containing $c a .30 \%$ of its anti-2b epimer.

$[\alpha]_{\mathrm{D}}=+138.8\left(c\right.$ 2.4, $\left.\mathrm{CHCl}_{3}\right) . \mathrm{NMR}$ data: $\delta_{\mathrm{H}}\left(\mathrm{CDCl}_{3}\right) 3.91(\mathrm{~m}, 1 \mathrm{H}, \mathrm{NHH}, \mathrm{M}+\mathrm{m}), 3.95(\mathrm{dd}$, $0.8 \mathrm{H}, J=6.9,4.88 \mathrm{~Hz}, \mathrm{H} 4, \mathrm{M}), 4.08(\mathrm{dd}, 0.2 \mathrm{H}, J=5.1,3.7 \mathrm{~Hz}, \mathrm{H} 4, \mathrm{~m}), 4.12$ (dt, 0.8H, $J=5.6$, $1.5 \mathrm{~Hz}, \mathrm{NH} H, \mathrm{M}), 4.20(\mathrm{dt}, 0.2 \mathrm{H}, J=5.6,1.5 \mathrm{~Hz}, \mathrm{NH} H, \mathrm{~m}), 4.53$ (dd, $1 \mathrm{H}, J=13.2,8.3 \mathrm{~Hz}$, $\left.\mathrm{C} H \mathrm{H}-\mathrm{NO}_{2}, \mathrm{M}+\mathrm{m}\right), 4.66\left(\mathrm{dd}, 1 \mathrm{H}, J=13.2,2.9 \mathrm{~Hz}, \mathrm{CH} H-\mathrm{NO}_{2}, \mathrm{M}+\mathrm{m}\right), 4.76(\mathrm{~m}, 1 \mathrm{H}, \mathrm{CH}-\mathrm{OH}$, $\mathrm{M}+\mathrm{m}), 5.31\left(\mathrm{~m}, 3 \mathrm{H}, \mathrm{H} 3+\mathrm{CH}=\mathrm{CH}_{2}, \mathrm{M}+\mathrm{m}\right), 5.83\left(\mathrm{~m}, 1 \mathrm{H}, \mathrm{CH}=\mathrm{CH}_{2}, \mathrm{M}+\mathrm{m}\right), 7.08(\mathrm{~m}, 3 \mathrm{H}, \mathrm{Ar}$, $\mathrm{M}+\mathrm{m}), 7.32(\mathrm{~m}, 2 \mathrm{H}, \mathrm{Ar}, \mathrm{M}+\mathrm{m}) . \delta_{\mathrm{C}}\left(\mathrm{CDCl}_{3}\right) 165.6(\mathrm{NC}=\mathrm{O}, \mathrm{M}+\mathrm{m}), 156.9(\mathrm{C}, \mathrm{Ar}, \mathrm{M}+\mathrm{m}), 131.4$ $\left(\mathrm{CH}=\mathrm{CH}_{2}, \mathrm{M}\right), 130.8\left(\mathrm{CH}=\mathrm{CH}_{2}, \mathrm{~m}\right), 129.8(\mathrm{CH}, \mathrm{Ar}, \mathrm{M}+\mathrm{m}), 123.3(\mathrm{CH}, \mathrm{Ar}, \mathrm{m}), 123.0(\mathrm{CH}, \mathrm{Ar}$, M), $119.8\left(\mathrm{CH}=\mathrm{CH}_{2}, \mathrm{~m}\right), 119.4\left(\mathrm{CH}=\mathrm{CH}_{2}, \mathrm{M}\right), 115.8(\mathrm{CH}, \mathrm{Ar}, \mathrm{M}+\mathrm{m}), 81.1(\mathrm{C} 3, \mathrm{~m}), 80.0(\mathrm{C} 3$, M), $77.9\left(\mathrm{OCH}_{2}, \mathrm{~m}\right), 77.6\left(\mathrm{OCH}_{2}, \mathrm{M}\right), 69.0(\mathrm{OCH}, \mathrm{M}), 67.5(\mathrm{OCH}, \mathrm{m}), 58.5(\mathrm{C} 4, \mathrm{~m}), 57.9(\mathrm{C} 4$, M), $44.5\left(\mathrm{NCH}_{2}, \mathrm{M}\right), 44.2\left(\mathrm{NCH}_{2}, \mathrm{~m}\right)$. IR $\left(\mathrm{CHCl}_{3}, \mathrm{~cm}^{-1}\right): v 3412(\mathrm{OH}), 1754(\mathrm{C}=\mathrm{O}), 1512$ $\left(\mathrm{NO}_{2}\right)$. MS (ES), $m / z: 293\left(\mathrm{M}^{+}+1,100\right), 292\left(\mathrm{M}^{+}, 9\right)$. Anal. Calcd for $\mathrm{C}_{14} \mathrm{H}_{16} \mathrm{~N}_{2} \mathrm{O}_{5}: \mathrm{C}, 57.53 ; \mathrm{H}$, 5.52; N, 9.58. Found: C, 57.66; H, 5.56; N, 9.53.

Nitroaldol syn-(+) 4c. From $47 \mathrm{mg}(0.20 \mathrm{mmol})$ of aldehyde (+)-1c, after column chromatography eluting with hexanes/ethyl acetate $(2: 1), 39 \mathrm{mg}(65 \%)$ of nitroaldol syn-(+)-4c was obtained as a colorless oil, containing $c a$. $20 \%$ of its anti-2c epimer.

$[\alpha]_{\mathrm{D}}=+172\left(c\right.$ 3.6, $\left.\mathrm{CH}_{2} \mathrm{Cl}_{2}\right)$. NMR data: $\delta_{\mathrm{H}}\left(\mathrm{CDCl}_{3}\right) 3.69\left(\mathrm{~s}, 2.4 \mathrm{H}, \mathrm{OCH}_{3}, \mathrm{M}\right), 3.71(\mathrm{~s}, 0.6 \mathrm{H}$, $\left.\mathrm{OCH}_{3}, \mathrm{~m}\right), 3.78\left(\mathrm{~s}, 3 \mathrm{H}, \mathrm{OCH}_{3}, \mathrm{M}+\mathrm{m}\right), 4.42(\mathrm{~m}, 1 \mathrm{H}, \mathrm{H} 4, \mathrm{M}+\mathrm{m}), 4.55\left(\mathrm{~m}, 2 \mathrm{H}, \mathrm{CH}_{2}-\mathrm{NO}_{2}, \mathrm{M}+\mathrm{m}\right)$, $4.69(\mathrm{~d}, 0.8 \mathrm{H}, J=5.1 \mathrm{~Hz}, \mathrm{H} 3, \mathrm{M}), 4.72(\mathrm{~d}, 0.2 \mathrm{H}, J=5.3 \mathrm{~Hz}, \mathrm{H} 3), 4.84(\mathrm{~m}, 1 \mathrm{H}, \mathrm{CH}-\mathrm{OH}, \mathrm{M}+\mathrm{m})$, $6.88(\mathrm{~m}, 2 \mathrm{H}, \mathrm{Ar}, \mathrm{M}+\mathrm{m}), 7.39(\mathrm{~m}, 2 \mathrm{H}, \mathrm{Ar}, \mathrm{M}+\mathrm{m}) . \delta_{\mathrm{C}}\left(\mathrm{CDCl}_{3}\right) 164.1(\mathrm{NC}=\mathrm{O}, \mathrm{M}), 163.7(\mathrm{NC}=\mathrm{O}$, 
m), $157.0(\mathrm{C}, \mathrm{Ar}, \mathrm{M}+\mathrm{m}), 129.8$ (C, Ar, M), 129.6 (C, Ar, m), 119.8 (CH, Ar, M), 119.3 (CH, Ar, m), $114.5(\mathrm{CH}, \mathrm{Ar}, \mathrm{m}), 114.4(\mathrm{CH}, \mathrm{Ar}, \mathrm{M}), 82.7(\mathrm{C} 3, \mathrm{~m}), 82.4(\mathrm{C} 3, \mathrm{M}), 77.5\left(\mathrm{OCH}_{2}, \mathrm{~m}\right), 77.3$ $\left(\mathrm{OCH}_{2}, \mathrm{M}\right), 68.5(\mathrm{OCH}, \mathrm{M}), 67.0(\mathrm{OCH}, \mathrm{m}), 59.7(\mathrm{C} 4, \mathrm{~m}), 59.6(\mathrm{C} 4, \mathrm{M}), 58.4\left(\mathrm{OCH}_{3}, \mathrm{~m}\right), 57.8$ $\left(\mathrm{OCH}_{3}, \mathrm{M}\right), 55.4\left(\mathrm{OCH}_{3}, \mathrm{M}+\mathrm{m}\right)$. IR $\left(\mathrm{CHCl}_{3}, \mathrm{~cm}^{-1}\right): v 3414(\mathrm{OH}), 1751(\mathrm{C}=\mathrm{O}), 1514\left(\mathrm{NO}_{2}\right) . \mathrm{MS}$ (ES), $m / z: 297\left(\mathrm{M}^{+}+1,100\right), 296\left(\mathrm{M}^{+}, 7\right)$. Anal. Calcd for $\mathrm{C}_{13} \mathrm{H}_{16} \mathrm{~N}_{2} \mathrm{O}_{6}: \mathrm{C}, 52.70 ; \mathrm{H}, 5.44 ; \mathrm{N}$, 9.46. Found: C, 52.58; H, 5.40; N, 9.40 .

Synthesis of Nitroaldols syn-(+) 4d and anti-(+) 4d. From $55 \mathrm{mg}(0.19 \mathrm{mmol})$ of aldehyde $(+)-$ 1d, after column chromatography eluting with hexanes/ethyl acetate (2:1), allowed to obtain 24 mg (36\%) of compound syn-(+)-4d as a colorless oil, $[\alpha]_{\mathrm{D}}=+107.7$ (c 2.2, $\left.\mathrm{CH}_{2} \mathrm{Cl}_{2}\right)$, as well as 6 $\mathrm{mg}(9 \%)$ of compound anti-(+)-4d as a colorless oil, $[\alpha]_{\mathrm{D}}=+36.8\left(\mathrm{c} 1.2, \mathrm{CH}_{2} \mathrm{Cl}_{2}\right)$.

NMR data of nitroaldol syn-(+)-4d: $\delta_{\mathrm{H}}\left(\mathrm{CDCl}_{3}\right) 3.7\left(\mathrm{~s}, 3 \mathrm{H}, \mathrm{OCH}_{3}\right), 4.42(\mathrm{dd}, 1 \mathrm{H}, J=6.4,5.6 \mathrm{~Hz}$, H4), 4.59 (m, 2H, $\left.\mathrm{CH}_{2}-\mathrm{NO}_{2}\right), 4.70$ (d, 1H, J=5.6 Hz, H3), 4.83 (m, 1H, CH-OH), 7.42 (m, 4H, Ar). $\delta_{\mathrm{C}}\left(\mathrm{CDCl}_{3}\right) 164.7(\mathrm{NC}=\mathrm{O}), 135.9(\mathrm{C}, \mathrm{Ar}), 132.2(\mathrm{CH}, \mathrm{Ar}), 119.7(\mathrm{CH}, \mathrm{Ar}), 117.9(\mathrm{C}, \mathrm{Ar})$, $82.2(\mathrm{C} 3), 77.3\left(\mathrm{OCH}_{2}\right), 68.8(\mathrm{OCH}), 59.8\left(\mathrm{OCH}_{3}\right), 57.8(\mathrm{C} 4)$. IR $\left(\mathrm{CHCl}_{3}, \mathrm{~cm}^{-1}\right): v 3416(\mathrm{OH})$, $1749(\mathrm{C}=\mathrm{O}), 1515\left(\mathrm{NO}_{2}\right)$. MS (ES), $m / z: 347\left(\mathrm{M}^{+}+\mathrm{H}+2,100\right), 346\left(\mathrm{M}^{+}+2,22\right), 344\left(\mathrm{M}^{+}, 25\right)$. Anal. Calcd for $\mathrm{C}_{12} \mathrm{H}_{13} \mathrm{~N}_{2} \mathrm{O}_{5} \mathrm{Br}$ : C, 41.76; H, 3.80; N, 8.12. Found: C, 41.91; H, 3.85; N, 8.19.

NMR data of nitroaldol anti-(+)-4d: $\delta_{\mathrm{H}}\left(\mathrm{CDCl}_{3}\right) 3.72\left(\mathrm{~s}, 3 \mathrm{H}, \mathrm{OCH}_{3}\right), 4.44(\mathrm{dd}, 1 \mathrm{H}, J=5.4,2.4$ $\mathrm{Hz}, \mathrm{H} 4), 4.51$ (dd, 1H, $\left.J=13.7,8.5 \mathrm{~Hz}, \mathrm{CH}-\mathrm{NO}_{2}\right), 4.68$ (dd, 1H, $J=13.7,3.9 \mathrm{~Hz}, \mathrm{CH} H-\mathrm{NO}_{2}$ ), $4.77(\mathrm{~d}, 1 \mathrm{H}, J=5.4 \mathrm{~Hz}, \mathrm{H} 3), 4.84(\mathrm{~m}, 1 \mathrm{H}, \mathrm{CH}-\mathrm{OH}), 7.45(\mathrm{~m}, 4 \mathrm{H}, \mathrm{Ar}) . \delta_{\mathrm{C}}\left(\mathrm{CDCl}_{3}\right) 164.1$ $(\mathrm{NC}=\mathrm{O}), 135.5(\mathrm{C}, \mathrm{Ar}), 132.4(\mathrm{CH}, \mathrm{Ar}), 120.1(\mathrm{C}, \mathrm{Ar}), 119.2(\mathrm{CH}, \mathrm{Ar}), 82.8(\mathrm{C} 3), 77.4\left(\mathrm{OCH}_{2}\right)$, $66.8(\mathrm{OCH}), 60.0\left(\mathrm{OCH}_{3}\right), 58.6(\mathrm{C} 4)$. IR $\left(\mathrm{CHCl}_{3}, \mathrm{~cm}^{-1}\right): v 3414(\mathrm{OH}), 1748(\mathrm{C}=\mathrm{O}), 1512\left(\mathrm{NO}_{2}\right)$. MS (ES), $m / z: 347\left(\mathrm{M}^{+}+\mathrm{H}+2,100\right), 346\left(\mathrm{M}^{+}+2,16\right), 344\left(\mathrm{M}^{+}, 18\right)$. Anal. Calcd for $\mathrm{C}_{12} \mathrm{H}_{13} \mathrm{~N}_{2} \mathrm{O}_{5} \mathrm{Br}$ : C, 41.76; H, 3.80; N, 8.12. Found: C, 41.90; H, 3.75; N, 8.18.

Synthesis of Nitroaldols syn-(+) 4 e and anti-(+) 4e. From $177 \mathrm{mg}(0.49 \mathrm{mmol})$ of aldehyde $(+)-$ 1e, after column chromatography eluting with hexanes/ethyl acetate (1:1), allowed to obtain 72 mg (35\%) of compound syn-(+)-4e as a colorless solid, mp $153-155{ }^{\circ} \mathrm{C}$ (hexanes/ethyl acetate), $[\alpha]_{\mathrm{D}}=+56.7\left(c 1.2, \mathrm{CH}_{2} \mathrm{Cl}_{2}\right)$, as well as $42 \mathrm{mg}(20 \%)$ of compound anti-(+)-4e as a colorless oil, $[\alpha]_{\mathrm{D}}=+50.2\left(c 1.8, \mathrm{CH}_{2} \mathrm{Cl}_{2}\right)$. NMR data of nitroaldol syn-(+)-4e: $\delta_{\mathrm{H}}$ (benzene-d $\left.\mathrm{d}_{6}\right) 3.11(\mathrm{~s}, 3 \mathrm{H}$, $\left.\mathrm{OCH}_{3}\right), 3.29\left(\mathrm{~s}, 3 \mathrm{H}, \mathrm{OCH}_{3}\right), 3.43(\mathrm{dd}, 1 \mathrm{H}, J=7.9,5.4 \mathrm{~Hz}, \mathrm{H} 4), 3.72$ (dd, $1 \mathrm{H}, J=12.9,2.3 \mathrm{~Hz}$, $\left.\mathrm{C} H \mathrm{H}-\mathrm{NO}_{2}\right), 3.89$ (dd, 1H, $\left.J=12.9,9.4 \mathrm{~Hz}, \mathrm{CH} H-\mathrm{NO}_{2}\right), 4.30(\mathrm{~m}, 1 \mathrm{H}, \mathrm{CH}-\mathrm{OH}), 5.79$ (d, $1 \mathrm{H}, J=$ $5.4 \mathrm{~Hz}, \mathrm{H} 3$ ), 6.64 (d, 2H, $J=9.0 \mathrm{~Hz}, \mathrm{Ar}), 6.75$ (d, 2H, $J=9.0 \mathrm{~Hz}, \mathrm{Ar}), 7.52$ (d, 2H, $J=9.0 \mathrm{~Hz}$, Ar), $8.07(\mathrm{~d}, 2 \mathrm{H}, J=9.0 \mathrm{~Hz}, \mathrm{Ar}) . \delta_{\mathrm{C}}\left(\mathrm{CDCl}_{3}\right) 165.2(\mathrm{NC}=\mathrm{O}), 164.9(\mathrm{C}=\mathrm{O}), 162.3(\mathrm{C}, \mathrm{Ar}), 157.6$ (C, Ar), 132.7 (CH, Ar), 130.3 (C, Ar), 120.4 (CH, Ar), 120.3 (C, Ar), 114.9 (CH, Ar), 114.6 $(\mathrm{CH}, \mathrm{Ar}), 77.6\left(\mathrm{OCH}_{2}\right), 74.0(\mathrm{C} 3), 69.0(\mathrm{OCH}), 58.7(\mathrm{C} 4), 56.0\left(\mathrm{OCH}_{3}\right), 55.9\left(\mathrm{OCH}_{3}\right) . \mathrm{IR}(\mathrm{KBr}$, $\left.\mathrm{cm}^{-1}\right)$ : v $3421(\mathrm{OH}), 1763(\mathrm{C}=\mathrm{O}), 1750,1512\left(\mathrm{NO}_{2}\right)$. MS (ES), $m / z: 417\left(\mathrm{M}^{+}+1,100\right), 416\left(\mathrm{M}^{+}\right.$, 15). Anal. Calcd for $\mathrm{C}_{20} \mathrm{H}_{20} \mathrm{~N}_{2} \mathrm{O}_{8}$ : C, 57.69; H, 4.84; N, 6.73. Found: C, 57.79; H, 4.81; N, 6.76. NMR data of nitroaldol anti-(+)-4e: $\delta_{\mathrm{H}}\left(\mathrm{CDCl}_{3}\right) 3.81\left(\mathrm{~s}, 3 \mathrm{H}, \mathrm{OCH}_{3}\right), 3.88\left(\mathrm{~s}, 3 \mathrm{H}, \mathrm{OCH}_{3}\right), 4.43$ (dd, $1 \mathrm{H}, J=13.7,9.5 \mathrm{~Hz}, \mathrm{CHH}-\mathrm{NO}_{2}$ ), 4.65 (dd, $\left.1 \mathrm{H}, J=5.4,2.7 \mathrm{~Hz}, \mathrm{H} 4\right), 4.71$ (dd, $1 \mathrm{H}, J=13.7$, 
$\left.2.2 \mathrm{~Hz}, \mathrm{CH} H-\mathrm{NO}_{2}\right), 4.82(\mathrm{dt}, 1 \mathrm{H}, J=9.7,2.2 \mathrm{~Hz}, \mathrm{CH}-\mathrm{OH}), 6.28(\mathrm{~d}, 1 \mathrm{H}, J=5.4 \mathrm{~Hz}, \mathrm{H} 3), 6.93$

$(\mathrm{m}, 4 \mathrm{H}, \mathrm{Ar}), 7.56$ (d, 2H, $J=9.0 \mathrm{~Hz}, \mathrm{Ar}), 8.01$ (d, 2H, $J=9.0 \mathrm{~Hz}, \mathrm{Ar}) . \delta_{\mathrm{C}}\left(\mathrm{CDCl}_{3}\right) 164.8$ $(\mathrm{NC}=\mathrm{O}), 164.4(\mathrm{C}=\mathrm{O}), 161.6(\mathrm{C}, \mathrm{Ar}), 157.2(\mathrm{C}, \mathrm{Ar}), 132.2(\mathrm{CH}, \mathrm{Ar}), 129.8(\mathrm{C}, \mathrm{Ar}), 119.8(\mathrm{C}$, Ar), $119.3(\mathrm{CH}, \mathrm{Ar}), 114.6(\mathrm{CH}, \mathrm{Ar}), 114.1(\mathrm{CH}, \mathrm{Ar}), 77.6\left(\mathrm{OCH}_{2}\right), 73.7(\mathrm{C} 3), 67.3(\mathrm{OCH}), 60.2$ (C4), $55.5\left(\mathrm{OCH}_{3}\right), 55.4\left(\mathrm{OCH}_{3}\right)$. IR $\left(\mathrm{CHCl}_{3}, \mathrm{~cm}^{-1}\right): v 3419(\mathrm{OH}), 1761(\mathrm{C}=\mathrm{O}), 1751,1514$ $\left(\mathrm{NO}_{2}\right)$. MS (ES), $m / z: 417\left(\mathrm{M}^{+}+1,100\right), 416\left(\mathrm{M}^{+}, 11\right)$. Anal. Calcd for $\mathrm{C}_{20} \mathrm{H}_{20} \mathrm{~N}_{2} \mathrm{O}_{8}: \mathrm{C}, 57.69$; H, 4.84; N, 6.73. Found: C, 57.81; H, 4.80; N, 6.69.

\section{Acknowledgements}

Support for this work by the DGI-MCYT (Project CTQ2006-10292) and CAM-UCM (Grant GR45/05) is gratefully acknowledged.

\section{References}

1. See, for example: Setti, E. L.; Micetich, R. G. Curr. Med. Chem. 1998, 5, 101. The Organic Chemistry of $\beta$-Lactams; Georg, G. I., Ed.; VCH: New York, 1993. Neuhaus, F. C.; Georgeopapadakou, N. H. In Emerging Targets in Antibacterial and Antifungal Chemoterapy; Sutcliffe, J.; Georgeopapadakou, N. H., Eds.; Chapman and Hall: New York, 1992. The Chemistry of $\beta$-Lactams; Page, M. I., Ed.; Chapman and Hall: London, 1992.

2. Some of the more notable advances concern the development of mechanism-based serine protease inhibitors of elastase, cytomegalovirus protease, thrombin, prostate specific antigen, and cell metastasis and as inhibitors of acyl-CoA cholesterol acyl transferase. For reviews, see: Veinberg, G.; Vorona, M.; Shestakova, I.; Kanepe, I.; Lukevics, E. Curr. Med. Chem. 2003, 10, 1741. Clader, J. W. J. Med. Chem. 2004, 47, 1. For recent selected examples, see: Kvaerno, L.; Ritter, T.; Werder, M.; Hauser, H.; Carreira, E. M. Ang. Chem. Int. Ed. 2004, 43, 4653. Burnett, D. A. Curr. Med. Chem. 2004, 11, 1873. (e) Page, M. I.; Laws, A. P. Tetrahedron 2000, 56, 5631. Haley, T. M.; Angier, S. J.; Borthwick, A. D.; Singh, R.; Micetich, R. G. Drugs 2000, 3, 512.

3. Rothstein, J. D.; Patel, S.; Regan, M. R.; Haenggeli, C.; Huang, Y. H.; Bergles, D. E.; Jin, L.; Hoberg, M. D.; Vidensky, S.; Chung, D. S.; Toan, S. V.; Bruijn, L. I.; Su, Z.-z.; Gupta, P.; Fisher, P. B. Nature 2005, 433, 73.

4. For reviews, see: Alcaide, B.; Almendros, P. Curr. Med. Chem. 2004, 11, 1921. Deshmukh, A. R. A. S.; Bhawal, B. M.; Krishnaswamy, D.; Govande, V. V.; Shinkre, B. A.; Jayanthi, A. Curr. Med. Chem. 2004, 11, 1889. Alcaide, B.; Almendros, P. Synlett 2002, 381. Alcaide, B.; Almendros, P. Chem. Soc. Rev. 2001, 30, 226. Palomo, C.; Aizpurua, J. M.; Ganboa, I.; Oiarbide, M. Synlett 2001, 1813. Alcaide, B.; Almendros, P. Org. Prep. Proced. Int. 2001, 33, 315. Palomo, C.; Aizpurua, J. M.; Ganboa, I.; Oiarbide, M. Amino-acids, 1999, 16, 321. 
Ojima, I.; Delaloge, F. Chem. Soc. Rev. 1997, 26, 377. Ojima, I. Adv. Asym. Synth. 1995, 1, 95. Manhas, M. S.; Wagle, D. R.; Chiang, J.; Bose, A. K. Heterocycles 1988, 27, 1755.

5. See, for example: Enders, D.; Reinhold, U. Angew. Chem., Int. Ed. 1995, 34, 1219. Rich, D. H. Peptidase Inhibitors In Comprehensive Medicinal Chemistry, Sammes, P. G.; Ed.; Pergamon Press: Oxford, 1990, Vol. 2, p 391. Huff, J. R. J. Med. Chem. 1991, 34, 2305. Thaisrivongs, S.; Pals, D. T.; Kroll, L. T.; Turner, S. R.; Han, F.-S. J. Med. Chem. 1987, 30, 976.

6. For selected reviews, see: Modern Aldol Reactions; Mahrwald, R., Ed.; Wiley-VCH: Weinheim, 2004. Palomo, C.; Oiarbide, M.; García, J. M. Chem. Soc. Rev. 2004, 33, 65. Alcaide B.; Almendros, P. Angew. Chem. Int. Ed. 2003, 42, 858. Palomo, C.; Oiarbide, M.; García, J. M. Chem. Eur. J. 2002, 8, 37. Alcaide B.; Almendros, P. Eur. J. Org. Chem. 2002, 1595. Machajewski, T. D.; Wong, C.-H. Angew. Chem. Int. Ed. 2000, 39, 1352.

7. For a review, see: Palomo, C.; Oiarbide, M.; Mielgo, A. Angew. Chem. Int. Ed. 2004, 43, 5442.

8. For selected reviews, see: Ono, N. The Nitro Group in Organic Synthesis, Wiley-VCH: New York, 2001. Luzio, F. A. Tetrahedron 2001, 57, 915. Ballini, R.; Bosica, G.; Fiorini, D.; Palmieri, A. Tetrahedron 2005, 61, 8971.

9. See, for instance: Alcaide, B.; Almendros, P.; Martínez del Campo, T. Angew. Chem. Int. Ed. 2006, 45, 4501. Alcaide B.; Almendros, P.; Redondo, M. C. Chem. Commun. 2006, 2616. Alcaide, B.; Almendros, P.; Alonso, J. M. Chem. Eur. J. 2006, 12, 2874. Alcaide, B.; Almendros, P.; Rodríguez-Acebes, R. J. Org. Chem. 2006, 71, 2346. Alcaide, B.; Almendros, P.; Aragoncillo, C.; Redondo, M. C.; Torres, M. R. Chem. Eur. J. 2006, 12, 1539.

10. Alcaide, B.; Almendros, P.; Luna, A.; Torres, M. R. J. Org. Chem. 2006, 71, 4818.

11. Palomo, C.; Oiarbide, M.; Laso, A. Angew. Chem. Int. Ed. 2005, 44, 3881.

12. For recents selected reviews, see: Tetrahedron 2006, 62, issues 2 and 3: Organocatalysis in organic synthesis, Kočovský, P.; Malkov, A. V. Guest Eds. Asymmetric Organocatalysis; Berkessel, A., Gröger, H., Eds.; Wiley-VCH: Weinheim, 2005. Seayad, J.; List, B. Org. Biomol. Chem. 2005, 3, 719-724. Dalko, P. I.; Moisan, D. L. Angew. Chem., Int. Ed. 2004, 43, 5138-5175. Johnson, J. S. Angew. Chem. Int. Ed. 2004, 43, 1326. Dalko, P. I.; Moisan, L. Angew. Chem. Int. Ed. 2001, 40, 3726.

13. The assignment of relative configuration based on the observed coupling constant for methine protons $\mathrm{H} 3$ and $\mathrm{H} 4$ is a very well established criterion in $\beta$-lactam chemistry. See, for example: Alcaide, B.; Almendros, P.; Salgado, N. R.; Rodríguez-Vicente, A. J. Org. Chem., 2000, 65, 4453. Alcaide, B.; Aly, M. F.; Rodríguez, C.; Rodríguez-Vicente, A. J. Org. Chem., 2000, 65, 3453.

14. Alcaide, B.; Almendros, P.; Rodríguez-Acebes, R. J. Org. Chem. 2005, 70, 2713. Alcaide, B.; Almendros, P.; Aragoncillo, C. Chem. Eur. J. 2002, 8, 1719. Alcaide, B.; Almendros, P.; Salgado, N. R. J. Org. Chem. 2000, 65, 3310. 
15. X-ray data of syn-(+)-4e: crystallized from ethyl acetate $/ n$-hexane at $20{ }^{\circ} \mathrm{C} ; \mathrm{C}_{20} \mathrm{H}_{20} \mathrm{~N}_{2} \mathrm{O}_{8}\left(M_{\mathrm{r}}\right.$ $=416.38)$; orthorhombic; space group = P2(1)2(1)2(1); a = 7.2996(15) $\AA, \mathrm{b}=14.392(3) \AA ; \mathrm{c}$ $=19.190(4) \AA ; \beta=90$ deg.; $\mathrm{V}=2016.0(7) \AA^{3} ; \mathrm{Z}=4$; cd $=1.372 \mathrm{mg} \mathrm{m}^{-3} ; \mu=0.107 \mathrm{~mm}^{-1}$; $\mathrm{F}(000)=872$. A transparent crystal of $0.45 \times 0.09 \times 0.04 \mathrm{~mm}^{3}$ was used. 3514 [R(int) = 0.1395] independent reflections were collected on a Bruker Smart CCD difractomer using graphite-monochromated Mo-K $\alpha$ radiation $(\lambda=0.71073 \AA)$ operating at $50 \mathrm{Kv}$ and $30 \mathrm{~mA}$. Data were collected over a hemisphere of the reciprocal space by combination of three exposure sets. Each exposure of $20 \mathrm{~s}$ and 30 s covered 0.3 in $\omega$. The structure was solved by direct methods and Fourier synthesis. It was refined by full-matrix least-squares procedures on $\mathrm{F}^{2}$ (SHELXL-97). All non-hydrogen atoms were refined anisotropically and all hydrogen atoms were included in calculated positions and refined riding on the respective carbon or oxygen atoms. Final $\mathrm{R}(\mathrm{Rw})$ values were 0.0534 (0.1166) and 0.1973 (0.1596). CCDC610275 contains the supplementary crystallographic data for this paper. These data can be obtained free of charge via the http://www.ccdc.can.ac.uk/conts/retrieving.html (or from the Cambridge Crystallographic Centre, 12 Union Road, Cambridge CB21EZ, UK; Fax (+44)1223-336033; or deposit@.cccdc.cam.ac.uk). 